\title{
CORRESPONDENCE
}

\section{The type material of Didymograptus hirundo Salter}

Didymograptus hirundo Salter, 1863, is well known as giving its name to the highest graptolite zone in the British Arenig Series. Although the species has frequently been referred to, it has not been revised since 1901, when Elles \& Wood (pl. 1, fig. 5c) reillustrated Salter's (1863) figured specimen (British Geological Survey no. GSM 6803, shown here in Fig. 1) which they referred to as the 'type specimen'; since Salter (1863, table, p. 138) evidently saw more than one specimen, I take Elles \& Wood's indication to be a lectotype designation. The only other possible syntype known to me is a distal fragment in the Harkness collection (Carlisle Museum 126-1978, no. 4). It is possibly, but not definitely, referable to $D$. hirundo (Fig. 2). The species is currently being revised, as part of a wider study, by Dr R. A. Fortey.

The locality of the lectotype was stated by Elles \& Wood to be Ellergill, a locality in the Cross Fell Inlier well known to yield graptolites from the upper part of the lower Llanvirn (Arthurton \& Wadge, 1981, p. 13). Elles \& Wood were, however, mistaken; it is clear from the original accounts of Harkness $(1863$, p. 123$)$ and Salter $(1863$, p. 138$)$ that $D$. hirundo was collected only from Ellen Gill, that is from the headwaters of the river Ellen in the northern Lake District, about $5 \mathrm{~km}$ east-northeast of Bassenthwaite village.

The biostratigraphy of the Skiddaw Slates Group in Ellen Gill is very poorly known, though pre-Arenig beds have been reported at Trusmadoor, high on the south side of the valley (Rushton, 1985). Harkness (1863, p. 123) recorded graptolites from Ellen Gill, especially a branching form 'in considerable abundance'. To judge from specimens in his collection preserved in the Carlisle Museum, he may have been referring to branching traces (burrows?), like those figured by Salter (1863, fig. 14) as 'bryozoon?'. Searches by T. C. Nicholas (Sedgwick Museum collection) and by the Geological Survey in the upper reaches of the River Ellen have yielded only the crustacean Caryocaris wrightii Salter and trace fossils, together with a single declined Didymo- graptus fragment, a fauna that gives no definite indication of the age of the beds.

Downstream of Trusmadoor the river crosses a northsouth fault mapped by the Survey, and $500 \mathrm{~m}$ upstream from Crag Wood it enters a gorge cut mainly in flaggy slates. At the upper end of this gorge, mudstones dip southwestwards at $45^{\circ}$. Here I have found graptolites in situ at two localities in the right bank of the stream:

(1) at grid reference NY 27213441 C. wrightii and one specimen of $D$. hirundo (BGS RX1021-2, see Fig. 3) were collected. Even though this $D$. hirundo cannot be regarded as a topotype, it suggests that the original material of $D$. hirundo came from the mudstones in this area.

(2) At NY 27223438 , about $30 \mathrm{~m}$ upstream of locality (l) and apparently $15-20 \mathrm{~m}$ above it, a prolific collection includes the following (BGS RX931-1019):

Azygograptus lapworthi Nicholson (one specimen)

Dichograptus octobrachiatus (J. Hall) (octad and hexad forms)

Dichograptus sedgwickii Salter

Didymograptus cf. uniformis Elles \& Wood

Phyllograptus cf. typus J. Hall (one)

Pseudophyllograptus $\mathrm{cf}$. densus (Törnquist) (very numerous but small)

Tetragraptus harti T. S. Hall

Tetragraptus quadribrachiatus (J. Hall)

Sponge spicules (cruciform)

Caryocaris wrightii Salter

burrows

I found no biserial species, Pseudotrigonograptus or pendent didymograptids such as are typical of the highest Arenig Series. According to the criteria given by Jackson (1962) this assemblage represents the zone of Isograptus gibberulus, which underlies the hirundo Zone in the Arenig Series. From this it appears that the type specimen of $D$. hirundo most probably originates from the gibberulus Zone.

Although it is to be regretted that the horizon of the type of $D$. hirundo falls outside the zone to which it gives its name,
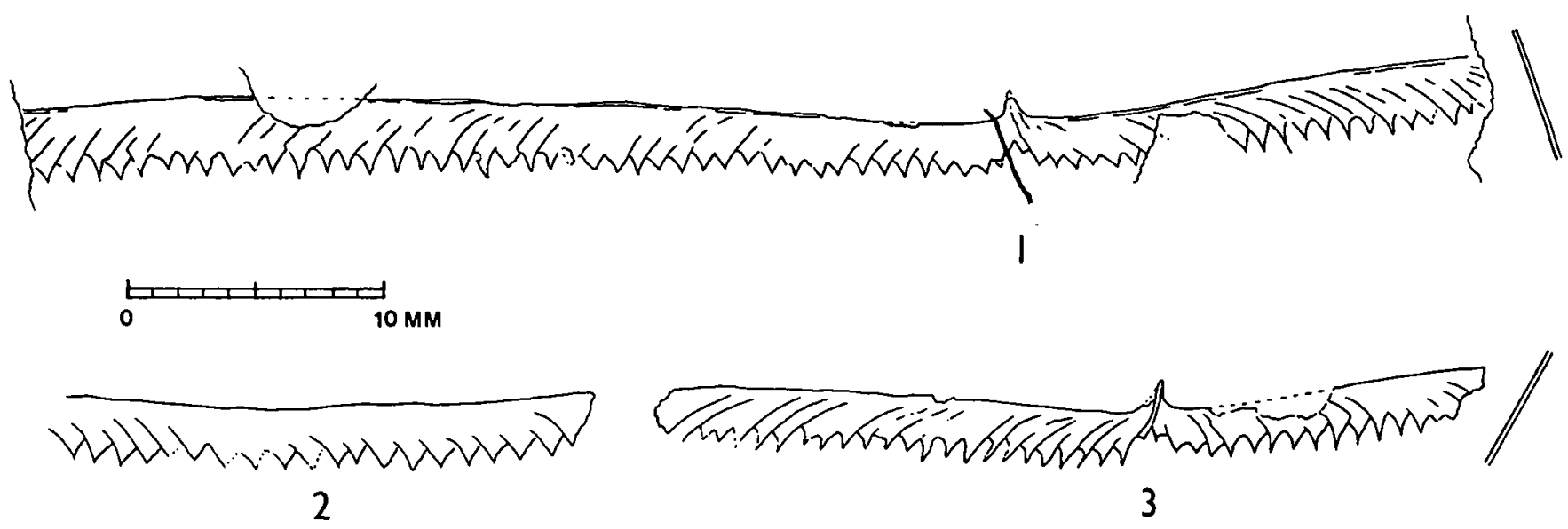

Figure 1. Didymograptus hirundo Salter, lectotype, BGS GSM6803. Ellen Gill, about $5 \mathrm{~km}$ east-northeast of Bassenthwaite, Cumbria (exact locality unknown).

Figure 2. D. hirundo? Possible syntype, Carlisle Museum 126-1978 no. 4, from 'Ellengill, Overwater', locality approximately as for Figure 1.

Figure 3. D. hirundo, BGS RX1021. Zone of 1 . gibberulus, 'Locality 1', Ellen Gill, grid ref. NY2721 3441.

Scale bar represents $10 \mathrm{~mm}$. The oblique lines in Figures 1 and 3 show the cleavage trace. 
Jenkins $(1982$, p. 243$)$ has already shown that the species ranges into strata below the hirundo Zone as defined by Jackson; and at least we are spared the biostratigraphical complications which might have arisen from supposing that the type of $D$. hirundo originated either from beds above the base of the Llanvirn or from below the base of the Arenig.

Acknowledgements. This letter is published by permisson of the Director, British Geological Survey, and is a contribution to the B.G.S. Lake District Regional Geological Survey. I thank Dr A. H. Cooper for assistance.

\section{References}

Arthurton, R. S. \& WadGe, A. J. 1981. Geology of the Country around Penrith. Memoir of the Geological Survey of Great Britain, $177 \mathrm{pp}$.

Elles, G. L. \& Wood, E. M. R. 1901. A monograph of British Graptolites. Part 1, pp. 1-54, pls 1-4. Monograph of the Palaeontographical Society, vol. for 1901.
HaRkNess, R. 1863. On the Skiddaw Slates. Quarterly Journal of the Geological Society of London 19, 113-35.

JACKSON, D. E. 1962. Graptolite zones in the Skiddaw Group in Cumberland, England. Journal of Paleontology 36, 300-13.

JENKINS, C. J. 1982. Isograptus gibberulus (Nicholson) and the isograptids of the Arenig Series (Ordovician) of England and Wales. Proceedings of the Yorkshire Geological Society 44, 219-48, pls. 16, 17.

Rushton, A. W. A. 1985. A Lancefieldian graptolite from the Lake District. Geological Magazine 122, in press.

Salter, J. W. 1863. Note on the Skiddaw Slate fossils. Quarterly Journal of the Geological Society of London 19, $135-140$.

\section{A. W. A. RUSHTON}

British Geological Survey

Keyworth

Nottingham NG12 5GG 